\title{
CORRESPONDENCE
}

\section{Alkaline $v$ calc-alkaline Late Palaeozoic volcanism in the Himalayas and some aspects on Himalayan geotectonics}

SIR - Sinha-Roy \& Furnes (1980) either missed or avoided answering specifically several pertinent points; they also raised some controversial issues on Himalayan geotectonics of general interest and thus in order for further correspondence.

\section{Calc-alkaline $v$ alkaline volcanism, their extent and nature of associated sediments}

Based on the comparison of general continental rift magmatic characters with only a few selected types of Late Palaeozoic Himalayan volcanics, Sinha-Roy \& Furnes have reaffirmed rift character of the Himalayan volcanics.

It is to be noted that the chemical character of island arc volcanic series is broadly dependent on the evolution stage of the arcs (Ringwood, 1974). Most often young arcs emit basalts and andesitic-basalts with an island arc tholeiitic trend. More developed arcs are characterised by mainly andesitic lavas with a calc-alkaline differentiation trend. The need for rigorous geochemical study of the variety of volcanics and volcaniclastics belonging to the Panjal, the Abor and other contemporaneous activity notwithstanding, available petrographic and broad chemical characters of the suite, as given in the references cited in Acharyya (1980), favour their calc-alkaline nature with minor alkaline components. Sinha Roy \& Furnes (1980) made reference to synsedimentary metavolcanics from central Nepal Lower Himalayas, which are associated with carbonates, slates and quartzites, and are suspected to be equivalent to the Panjal Trap. Homotaxial amphibolites from the same or adjacent areas show island arc tholeiitic character (Lasserre, 1977).

As already indicated by Acharyya (1980), a regional Late Palaeozoic-Early Mesozoic thermal event has been evidenced in the Lower Himalayas by clustering of $\mathrm{Rb} / \mathrm{Sr}$ total-rock isochron, $\mathrm{K} / \mathrm{Ar}$ total-rock and respective mineral ages. It is further noted that leucogranitic or pegmatitic phases of some of the Lower Himalayan Early Palaeozoic or older granitoids have yield Late Palaeozoic Rb/Sr total-rock ages. The leucogranitic phase of the Mandi area, indicating $311 \pm 6 \mathrm{MA}$ total-rock isochron, has significantly higher initial ${ }^{87} \mathrm{Sr} /{ }^{86} \mathrm{Sr}$ ratio $(0.81)$ compared to relatively low initial ratio $(0.70)$ for the Early Palaeozoic Mandi granite (Mehta, 1977). These Himalayan leucogranites and pegmatites, giving Late Palaeozoic $\mathrm{Rb} / \mathrm{Sr}$ total-rock ages, thus appear to be of crustal anatectic origin.

Sinha-Roy \& Furnes $(1978,1980)$ failed to appreciate the significance of remarkable lateral extension of the Late Palaeozoic Himalayan volcanics and closely associated marine to paralic sediments which occur in the Lower, the Tibetan and also in the Trans-Himalayan belts. Close lithological and faunal/floral similarity, particularly between the two former tectonic domains do not justify existence of any 'Central barrier' at least during Late Palaeozoic time (Acharyya et al. 1979). To consider only the tectonic distribution of the Lower Himalayan Late Palaeozoic rocks as the remnant of a linear southern basin is thus unjustified.

The Late Palaeozoic andesitic, basaltic volcanics and volcaniclastics of South Tibet and West Yunnan (Chang, 1963; AGSC, 1975) were loosely referred to as 'basic' by Sinha-Roy \& Furnes (1980). These volcanics are associated in space with Late Palaeozoic-Early Mesozoic granitoid batholiths (Chang, 1963; Chang \& Zdeng, 1973; AGSC, 1975). The Late Palaeozoic geotectonic setting of Tibet thus may be logically compared with those during Late Cenozoic collision.

The Late Palaeozoic paralic facies of the eastern Lower Himalayas have been said to contrast strongly with Late Palaeozoic-Early Mesozoic carbonates of the western sector by Sinha-Roy \& Furnes (1980). This conclusion is apparently based on facies comparison with the Blaini-Krol sequence as given in Krishnan (1956). This succession is very sparsely fossiliferous and recent fossil finds from different formations are neither consistent nor in regular stratigraphic order. This, as well as recent stratigraphic-structural study by the present writer, indicates that the Blaini-Krol sequence is intensely tectonized. The middle Krol, and the lower and the upper Tal beds have yielded broadly contemporaneous Late Mesozoic micro-fauna (Shrivastava \& Mehrotra, 1974; Sinha, 1975; Acharyya 
\& Ray, 1979). Dominantly carbonate facies characterizing the upper Krol therefore may be excluded while considering Late Palaeozoic-Early Mesozoic sediments. The Blaini diamictite and the Infra-Krol of the western Lower Himalayas closely resemble, both lithologically and biostratigraphically, the homotaxial Late Palaeozoic sediments from the eastern sector. The unfossiliferous Blaini carbonates may represent tectonic slivers from older beds. The Infra-Krol from Nainital area has yielded rich mega-flora with Gangamopteris-Glossopteris, as well as Cathaysian elements like Lepidodendron, Calamites, Annuleria, etc. (Tewari \& Singh, 1980). The Blaini beds from the same area have yielded Early Permian marine fauna with large fusulinid ?Robustoschwagerina (equivalent to ParafusulinaPseudo-schwagerina zone) (Tewari, 1980). In the area under reference, fusulinid fauna is only known so far from Salt Range, Kashmir, Ladakh and Tibet. Further, Robustoschwagerina, known from South Ferghana and Darwas in U.S.S.R., is a 'northern' fusulinid genus. The Blaini beds of the type area have also yielded micro-flora of 'northern' affinity (Shrivastava \& Venkataraman, 1975). GondwanaCathaysian mega-floral intercalations are well known from the Early Permian paralic beds from Kashmir Himalaya (Kapoor, 1979). Fusulinids have also been recorded from these beds (Azmi, 1976).

The Kashmir Gondwana and associated marine sediments are considered to be of Tibetan basin by those who distinguish between the Lower and Tibetan basin belts. Presence of GondwanaCathaysian floral intercalations and northern fusulinid genus from Nainital Lower Himalayas corroborate their northern (Tibetan) palinspastic distribution.

Sinha-Roy \& Furnes (1980) also made reference to the Jammu Limestone of Kashmir foothills, with Panjal type volcanics at their base and occurring unconformably below the Eocene sediments and about $25 \mathrm{~km}$ south of the Main Boundary Thrust or the Murree Thrust. These carbonates, apart from being ancient as indicated by Lower-Middle Riphean stromatolite assemblage (Raha \& Sastry, 1973), may not be autochthonous basement inliers as usually contemplated. Possibly these occur as downfaulted klippe of the Lower Himalayan rocks within the frontal schuppen zone of the Palaeogene sediments. The largest inlier of Jammu Limestone, occurring in the Riasi area about $45 \mathrm{~km}$ to the north of Jammu and about $50 \mathrm{~km}$ in length and $9 \mathrm{~km}$ or less in width, is associated with a negative Bouguer anomally (Rao \& Rao, 1979). The regional northeasterly decreasing negative Bouguer anomaly from Jammu foothills to Kashmir Himalayas and uniformity of such gravity anomaly pattern in other easterly located sections, which could be correlated with deep well sections and/or seismic structural map on top of the basement, indicate the persistent northerly sloping nature of Indian basement. Immediately to the east, along the axis of the Riasi inlier occurs the Udhampur syncline exposing an almost entire sequence from the Upper Murree (Lower Miocene) to the Upper Siwalik (Pleistocene). The contact between the Eocene sediments and the Jammu Limestone appears to be tectonized, and coal occurring at the base of the Eocene sequence has been intensely sheared and rendered anthracitic in rank. Recent study of Riasi area by S. K. Acharyya and K. K. Ray has revealed the presence of rhyolitic quartzite breccia and glassy volcanic breccia, which have been bauxitized at different levels. The agglomerates occur above the Jammu Limestone and below the Eocene sediments. Lithologically these compare closely with homotaxial carbonates and volcanics (Panjal) forming the nappe sequence above the Main Boundary Thrust or the Murree Thrust.

\section{Himalayan getectonics}

Sinha-Roy \& Furnes (1980) also failed to recognise the significance of recent reports of Late Mesozoic-Palaeogene sediments from some of the Lower Himalayan windows cited by Acharyya (1980). Occurrence of similar sediments on the subthrust side of a few crystalline nappes was known earlier. But similar fossiliferous sediments have now been recorded intimately associated with flyschoid-molassic unmetamorphosed sediments (?Palaeogene) and occurring tectonically below the older rocks of the Blaini-Krol (Krol nappe) sequence or the Miri-Gondwana sequence which have been reiterated as parautochthonous by Sinha-Roy. These Late Mesozoic-Palaeogene sediments occur in the frontal schuppen zone, as well as in the lowest structural levels of the Lower Himalayan windows from western, central and eastern sectors. The window sediments are often intersliced with the cover metamorphites due to schuppen structure, but these typically lack pre-Tertiary tectonic grain and metamorphism ubiquitously developed in the latter (Acharyya \& Ray, 1980). The northern limit of the Himalayan windows is located $20-70 \mathrm{~km}$ north of the frontal zone. The nature of occurrence and facies of these sediments and their intimate association with shell-limestones containing persistent Late 
Mesozoic marine fauna between Rishikesh to Nainital foothills, i.e. between $78^{\circ} \mathrm{E}$ to $79^{\circ} 30^{\prime} \mathrm{E}$, about $200 \mathrm{~km}$ in strike length, corroborate wide east-west, as well as northward palinspastic distribution of the Late Mesozoic-Palaeogene miogeosynclinal basin which is otherwise largely concealed under Lower Himalayan pre-Tertiary nappes.

Sinha-Roy \& Furnes (1980) appear to be overwhelmed by the magnitude of tectonic transport postulated in Ray \& Acharyya's (1976) model, wherein the Himalayan pre-Tertiary rocks are regarded as essentially allochthonous and brought from the Tibetan homeland. This problem is really beyond the scope of present correspondence. Recent geological and subsurface evidence substantiating the model has been dealt with elsewhere (Acharyya \& Ray, 1980). It may also be noted that with the help of seismic reflection profiling across the southern Appalachians, Cook et al. (1979) substantiated the role of thin-skinned tectonics and a structural model closely similar to that proposed for the Himalayas by Ray \& Acharyya (1976). The existence of relatively undeformed and unmetamorphosed sedimentary rocks covered extensively below crystalline or less metamorphosed allochthonous sheets thus may be a significant tectonic style of the major orogenic zones.

It may thus be concluded that Late Palaeozoic volcanics and volcaniclastics, of the Lower, the Tibetan-Himalayas and South Tibet, are dominantly of island arc and calc-alkaline type. Broad coincidence in time and space between the Late Palaeozoic-Early Mesozoic reworking of granitoid and metamorphic rocks in the Himalayas, south-central Tibet, and island arc type volcanism in these areas suggests partial melting of thickened and shortened continental crust. The Late Palaeozoic island arc zone appears to be located in the Tibetan homeland, north of the Palaeozoic-Mesozoic northern marine shelf of Gondwanic India. The former possibly provided passage ways for Gondwana and Cathaysian/Laurasian floral and land faunal admixtures recorded from Himalaya, Tibet and southeast Asia (Acharyya, 1978). Mesozoic-Cenozoic Himalayan miogeosyncline, developed on the northern shelf of Gondwanic India, was significantly concealed under the pre-Tertiary metamorphic nappe cover brought from the Tibetan homeland during Himalayan orogenesis.

\section{References}

Academy of Geological Sciences China. 1975. Geological map of Asia, 1:5 M (20 sheets). Beijing (Peking).

Acharyya, S. K. 1978. Mobile belts of the Burma-Malaya and the Himalaya and their implications on Gondwana and Cathaysia/Laurasia continent configurations. In Third Regional Conf. on Geology and Mineral Resources of SE Asia Bangkok, 1978 (ed. P. Nutalaya), pp. 121-7. Bangkok: Asian Institute of Technology.

Acharyya, S. K. 1980. Geochemistry and geotectonic implication of basic volcanic rocks in the Lower Gondwana sequence (Upper Palaeozoic) of the Sikkim Himalayas. Geol. Mag. 117, 621-9.

Acharyya, S. K. \& Ray, K. K. 1979. Structure of the Krol nappe and the age of 'Tal-shell limestone', Garhwal Himalaya. Indian Minerals. 33, 39-40.

Acharyya, S. K. \& Ray, K. K. 1980. Concealed Mesozoic-Palaeogene sediments below the Himalayan nappes, their hydrocarbon possibilities - reappraisal in the light of recent findings. Bull. Am. Ass. Petrol. Geol. (In the Press.)

Acharyya, S. K., Shah, S. C., Ghosh, S. C. \& Ghosh, R. N. 1979. Gondwana of the Himalaya and its biostratigraphy. In Fourth International Gondwana symposium Calcutta, India, 1977 (ed. B. Laskar and C. S. Raja Rao), pp. 420-33. Delhi, India: Hindustan Pub.

Azmi, R. J. 1976. Fusulinids from the Gangamopteris beds of Kashmir. In Sixth Colloq. Micropalaeontol. Stratigr. Benaras India (ed. M. S. Srinivasan), pp. 1-5.

Chang, Ta. 1963. The Geology of China. Translated in U.S. Department of Commerce Technical Services Joint Publication Res. Service, Washington, D.C.

Chang, Chen-fu \& Zdeng, Shi-lang. 1973. Tectonic features of the Mt Jolmo Lungma region in Southern Tibet, China. Sc. Geol. Sinica, 1973 1, 1-12.

Cook, F. A., Albaugh, D. S., Brown, L. D., Kaufman, S., Oliver, J. E. \& Hatcher, R. D. 1979. Thin-skinned tectonics in the crystalline southern Appalachians: COCORP siesmic reflection profiling of the Blue Ridge and Piedmont. Geology. 7, 563-7.

Kapoor, H. M. 1979. Gondwana of Kashmir - a reappraisal. In Fourth International Gondwana Symposium Calcutta, 1977 (ed. B. Laskar \& C. S. Raja Rao), pp. 443-53.

Krishnan, M. S. 1956. Geology of India and Burma. Madras: Higginbothams. 
Lasserre, J. L. 1977. Amphibolites and alkaline gneisses in the midland formations of Nepal, petrography, geochemistry-geodynamic involvements. In Himalaya Sci. Terre, Colloques International, pp. 213-36. Paris: CNRS.

Mehta, P. K. 1977. Rb-Sr geochronology of the Kulu-Mandi belt its implications for Himalayan tectogenesis. Geol. Rdsch. 66, 156-75.

Raha, P. K. \& Sastry, M. V. A. 1973. Stromatolites from Jammu Limestone north of Riasi dist. Udhampur, J. \& K., and their stratigraphic and palaeogeographic significance. Himalayan geol. $3,135-47$.

Rao, V. V. K. \& Rao, R. P. 1979. Geology of the Tertiary belt of north-west Himalaya, J \& K state, India. In Himalayan Geology Seminar New Delhi, 1976, Geol. Surv. India Misc. Pub. 41 (5), 149-73.

Ray, K. K. \& Acharyya, S. K. 1976. Concealed Mesozoic-Cenozoic Alpine Himalayan Geosyncline and its petroleum possibilities. Bull. Am. Ass. Petrol. Geol. 60, 794-808.

Ringwood, A. E. 1974. Petrological evolution of island arc systems. J. Geol. Soc. Lond. 130, 183-204.

Shrivastava, R. N. \& Mehrotra, P. C. 1974. Organic remains, age and environment of the Lower Tal Formation of Mussoorie synform, U.P. In Fifth Seminar Centre Adv. Study Geol. Panjab Univ. Chandigarh, 1974. (Abstr.)

Shrivastava, R. N. \& Venkataraman, K. 1975. Palynostratigraphy of the Blaini Formation. Ind. Geol. Ass. Spec. Issue 8 (2), 196-7.

Sinha, A. K. 1975. Calcareous nannofossils from Simla Hills (Himalaya India) with a discussion of their age in the tectono-stratigraphic column. J. Geol. Soc. India 16, 69-77.

Sinha-Roy, S. \& Furnes, H. 1978. Geochemistry and geotectonic implication of basic volcanic rocks in the Lower Gondwana sequence (Upper Palaeozoic) of the Sikkim Himalayas. Geol. Mag. 115, 427-36.

Sinha-Roy, S. \& Furnes, H. 1980. Alkaline vs Calc-alkaline continental magnatism: implications for Gondwanic Rift in the Himalayas. Geol. Mag. 117, 621-9.

Tewari, B. S. 1980. Stratigraphic significance of fossiliferous Blainis with fusulinids from Lesser Himalayas of Kumaon, India. Bull. Ind. Geol. Ass. 12, 257-8.

Tewari, B. S. \& Singh, R. Y. 1980. The significance and occurrence of Late Palaeozoic plant remains in the Infrakrol sequence of Nainital, U.P. Bull. Ind. Geol. Ass. 12, 263-6.

Geological Survey of India,

S. K. ACHARYYA

Manipur-Nagaland Circle,

Dimapur, Nagaland

India-797112

Sth September 1980 